\title{
Panpsychism proved
}

\section{Met with stony silence.}

\section{Rudy Rucker}

"There's a new way for me to find out what you're thinking," said Shirley, sitting down opposite her co-worker Rick in the lab's sunny cafeteria. She looked very excited, very pleased with herself.

"You've hired a private eye?" said Rick. "I promise, Shirley, we'll get together for something one of these days. I've been busy, is all. ${ }^{n}$ He seemed uncomfortable at being cornered by her.

"I've invented a new technology," said Shirley. ${ }^{\alpha}$ The mindlink. We can directly experience each other's thoughts. Let's do it now.

"Ah, but then you'd know way too much about me," said Rick, not wanting the conversation to turn serious. "A guy like me, I'm better off as a mystery man."

"The real mystery is why you aren't laid off," said Shirley tartly. "You need friends like me, Rick. And I'm dead serious about the mindlink. I do it with a special quantum jigglydoo. There will be so many applications."

"Like a way to find out what my boss thinks he asked me to do?"

"Communication, yes. The mindlink will be too expensive to replace the cell phone - at least for now - but it opens up the possibility of reaching the inarticulate, the mentally ill and, yeah, your boss. Emotions in a quandary? Let the mindlink techs debug you!"

"So now I'm curious," said Rick. "Let's see the quantum jiggly-doo."

Shirley held up two glassine envelopes, each holding a tiny pinch of black powder. "I have some friends over in the heavy hardware division, and they've been giving me microgram quantities of entangled pairs of carbon atoms. Each atom in this envelope of mindlink dust is entangled with an atom in this other one. The atom pairs' information is coherent but locally inaccessible - until the atoms get entangled with observer systems."

"And if you and I are the observers, that puts our minds in synch, huh?" said Rick. "Do you plan to snort your black dust off the cafeteria table or what?"

"Putting it on your tongue is fine," said Shirley, sliding one of the envelopes across the tabletop.
"You've tested it before?"

"First I gave it to a couple of monkeys. Bonzo watched me hiding a banana behind a door while Queenie was gone, and then I gave the dust to Bonzo and Queenie, and Queenie knew right away where the banana was.

¿I tried it with a catatonic person too. She and I swallowed mindlink dust together and I was able to single out the specific thought patterns tormenting her. I walked her through the steps in slow motion. It really helped her."

"You were able to get medical approval for that?" said Rick, looking dubious.

${ }^{\infty} \mathrm{No}$, I just did it. I hate red tape. And

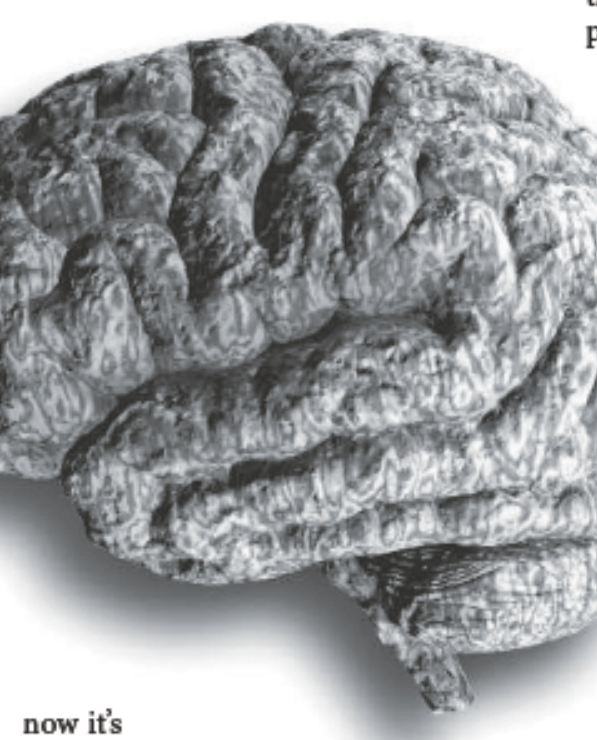

time for a peer-to-

peer test. With you,

Rick. Each of us swal-

lows our mindlink dust and makes notes on what we see in the other's mind."

"You're sure that the dust isn't toxic?" asked Rick, flicking the envelope with a fingernail.

"It's only carbon, Rick. In a peculiar kind of quantum state. Come on, it'll be fun. Our minds will be like websites for each other - we can click links and see what's in the depths."

"Like my drunk-driving arrest, my membership in a doomsday cult and the fact that I fall asleep sucking my thumb every night?"

"You're hiding something behind all those jokes, aren't you, Rick? Don't be scared of me. I can protect you. I can bring you along on my meteoric rise to the top."

Rick studied Shirley for a minute. ${ }^{\alpha}$ Tell you what," he said finally. "If we're gonna do a proper test, we shouldn't be sitting here face to face. People can read so much from each other's expressions." He gestured towards the boulder-studded lawn outside the cafeteria doors. "I'll go sit down where you can't see me."

"Good idea," said Shirley. "And then pour the carbon into your hand and lick it up. It tastes like burnt toast."

Shirley smiled, watching Rick walk across the cafeteria. He was so cute and nice. If only hed ask her out. Well, with any luck, while they were linked, she could reach into his mind and implant an obsessive loop centring around her. That was the real reason she'd chosen Rick as her partner for this mindlink session, which

was, if the truth be told, her tenth peerto-peer test.

She dumped the black dust into her hand and licked. Her theory and her tests showed that the mindlink effect always began in the first second after ingestion there was no need to wait for the body's metabolism to transport the carbon to the brain. This in itself was a surprising result, indicating that a person's mind was somehow distributed throughout the body, rather than sealed up inside the skull.

She closed her eyes and reached out for Rick. She'd enchant him and they'd become lovers. But, dammit, the mind at the other end of the link wasn't Rick's. No, the mind she'd linked to was inhuman: dense, taciturn, crystalline, serene, beautiful...

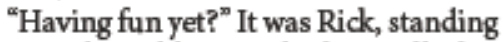
across the table, not looking all that friendly.

"What...." began Shirley.

"I dumped your powder on a boulder. You're too weird for me. I gotta ga."

Shirley walked slowly out of the patio doors to look at the friendly grey lump of granite. How nice to know that a rock had a mind. The world was cosier than shed ever realized. She'd be OK without Rick. She had friends everywhere.

Rudy Rucker's most recent non-fiction book is about the meaning of computation:

The Lifebox, the Seashell, and the Soul. See www. rud yrucker.com for further information. 